\title{
FORBIDDEN PAYMENT: FOREIGN BRIBERY AND AMERICAN BUSINESS \\ AFTER 1977
}

\begin{abstract}
The United States prohibits American individuals and corporations from bribing foreign government officials. Legislation enacted in 1976 and 1977 stipulates tax penalties, fines, and even prison terms for executives of American companies that pay illegal bribes. This paper examines the effect of US anti-bribery legislation on the operations of US firms in bribe-prone countries after 1977. Four separate indicators reveal that US business activities in these countries fell sharply after passage of the Foreign Corrupt Practices Act of 1977. These results suggest that this unilateral action by the United States served to weaken the competitive positions of American firms without significantly reducing the importance of bribery to foreign business transactions.
\end{abstract}

James R. Hines, Jr.

John F. Kennedy School of Government

Harvard University

79 John F. Kennedy Street

Cambridge, MA 02138

and NBER 
SENATOR Heinz. ${ }^{1}$ Are U.S. firms losing a substantial foreign business to non-U.S. companies who in fact are bribing, whereas we are not?

AMbASSADOR Brock. Yes.

SENATOR HEINZ. We are?

\section{Introduction.}

Bribery of government officials is a common business practice in some countries.

Firms pay bribes in order to obtain government contracts, to receive import licenses, and to forestall regulatory complications to which they might otherwise be subject. Foreign-owned firms often receive special attention from government officials seeking bribes.

Prior to 1977 , American multinationals routinely engaged in this practice. One byproduct of the Watergate investigation of the 1970s was the disclosure of numerous instances in which American firms bribed public officials in foreign countries, among them spectacular cases such as Lockheed's payments to the Tanaka government in Japan. This news was received with great disfavor by the American public. In response, Congress enacted legislation in 1976 and 1977 designed to punish and thereby eradicate foreign bribery by American firms.

This paper analyzes the impact of American anti-bribery laws on the performance of US business in the years after 1977. The purpose of the analysis is both to investigate the effect of these laws on American competitiveness and to use this episode to evaluate the importance of bribery to international commerce. The results indicate that American legislation significantly reduced US business activity in those countries in which government officials routinely receive bribes. The paper examines four indicators of US business activity in these countries: foreign direct investment (FDI), capital/labor ratios, joint venture activity, and aircraft exports. By all of these measures, US business activity in corrupt countries showed unusual declines after 1977. Business in corrupt countries fell by

\footnotetext{
${ }^{1}$ United States Senate (1981, p. 60).
} 
amounts that are associated with $30 \%$ reductions in local GDP.

These results do not conform to predictions made at the time that the American antibribery legislation was enacted. Its supporters believed that American legislation would inspire other nations to outlaw bribery, or otherwise discourage government officials from taking bribes, thereby removing any competitive disadvantage facing scrupulous firms. Even in the absence of international cooperation, if American firms compete primarily with each other in foreign markets, then bribery prohibitions might actually enhance their competitive positions. And failing that, the difficulty of enforcing the legislation leaves open the possibility that US firms would simply ignore its provisions, or find covert substitutes for bribes, in either case experiencing no competitive disadvantage.

Earlier empirical studies likewise conclude that US anti-bribery legislation did not reduce American business activity in corrupt countries. ${ }^{2}$ It is, however, important to distinguish the impact of US legislation from other factors that influence levels of US business activity, since foreign commerce fluctuates for many reasons that have nothing to do with bribery. The empirical work in this paper differs from earlier empirical investigations by including variables designed to control for general changes in levels of foreign economic activity. Once these controls are introduced, evidence of the impact of US legislation appears in even the simplest nonparametric statistics.

Section 2 of the paper describes the history of US anti-bribery legislation. Section 3 presents the data and empirical results. Section 4 considers the implications of these results.

\section{Background.}

The US anti-bribery legislation of the 1970s was one product of the Watergate scandal that followed the presidential election of 1972. The discovery that American corporations made

\footnotetext{
${ }^{2}$ See, for example, Graham (1984) and Beck, Maher, and Tschoegl (1991). In his survey of the literature, Richardson (1993) concludes that there is no evidence that American anti-bribery legislation affected exports by US firms.
} 
questionable contributions to President Nixon's re-election campaign stimulated numerous inquiries. Under US law, corporations are prohibited from contributing to federal election campaigns;

furthermore, corporations are subject to extensive reporting requirements. Investigations by the Watergate special prosecutor and the Senate Select Committee on Presidential Campaign Activities during 1973-1974 revealed many instances of illegal campaign contributions, laundering of funds to be used for illegal contributions, and failures to report these illegal uses of funds.

The reporting failures sparked an investigation by the Securities and Exchange Commission in 1974. At the same time, the SEC offered immunity from prosecution to firms willing to volunteer previously unreported information about improper domestic and foreign payments. In response, more than 400 corporations disclosed making illegal payments; of these disclosures, many described payments to foreign government officials. ${ }^{3}$ Starting in 1975 , the Internal Revenue Service began a separate program of questioning corporate officers and their accountants about the use of "slush funds" to pay bribes in the United States and abroad. By the end of 1976, the IRS identified more than 270 bribery cases on the basis of its survey results. ${ }^{4}$

These findings, along with rising pressure from the public and from Congress, impelled the Ford administration to propose corrective legislation in August, 1976. This legislation would require American companies to disclose their foreign bribe payments. The bribes would not themselves be illegal, but failure to disclose them would be; the idea was to discourage bribery by subjecting bribe payers and bribe recipients to public opprobrium (and, in certain countries, possible legal action). But members of Congress did not feel that disclosure alone was sufficient, arguing that

${ }^{3}$ See the description of the SEC findings in Comptroller General of the United States (1981). Smith, Stettler, and Beedles (1984) document that firms voluntarily reporting foreign bribe payments experienced abnormal negative stock market returns that are correlated with magnitudes of reported bribes. Market reactions may reflect either the public relations consequences of the disclosures or the effect of anticipated US anti-bribery legislation.

‘See Blumenthal (1977, p. 68). 
disclosure should be supplemented by criminalization of foreign bribe payments. An impasse between the Republican White House and the Democratically-controlled Congress stymied this legislation in 1976, though the Tax Reform Act of 1976 imposed new US tax penalties on the bribe-produced foreign income of American companies."

The Carter administration took office in January, 1977 in sympathy with Congressional anti-bribery sentiment and with a strong desire to distinguish its foreign policy from those of the preceding administrations. One early consequence was passage of the Foreign Corrupt Practices Act (FCPA) of 1977, which imposes fines and criminal penalties on American individuals responsible for bribing foreign government officials, and which mandates strict accounting changes intended to make it difficult for firms to hide bribe payments. It is a sign of the mood of the times that Congress passed the FCPA by a unanimous vote.

The FCPA adds a great deal of investigative and enforcement muscle to the deterrent effect of the 1976 tax legislation. Under the FCPA, firms caught paying bribes face fines of up to \$1 million, and individual employees face fines of up to $\$ 10,000$ and can receive prison sentences of up to five years. Furthermore, the FCPA includes provisions designed to prevent firms from paying bribes through third parties or other covert channels. Under the FCPA, it is illegal for Americans to make corrupt payments to foreign government officials or politicians, and it is also illegal to give money to any other person (such as shady "facilitating agents") if it is known or if there is reason to know that all or part of the money will be used for bribe payments. In addition, the FCPA requires firms to implement accounting and control procedures designed to prevent the surreptitious use of

'Three provisions of the Tax Reform Act of 1976 penalize American companies paying bribes to foreign officials. Under the Act, bribe payments cannot be deducted in calculating the earnings and profits of controlled foreign corporations, thereby reducing a firm's ability to claim foreign tax credits. Bribe payments represent deemed distributed income of controlled foreign corporations, subjecting them to immediate US taxation. And similarly, American exporters caught paying bribes lose US tax deferral (through DISCs or FSCs) of the bribery component of their export incomes. 
"slush funds" to make illegal bribe payments. At the same time, the FCPA contains an exception permitting Americans to make "grease" payments to minor ministerial or clerical officials of foreign governments who would otherwise perform their tasks too slowly. ${ }^{\circ}$

By 1981, Congress was holding hearings on amendments to the FCPA, prompted by concern over the possible chilling effect of US legislation on American business activity abroad. In response, the Tax Equity and Fiscal Responsibility Act of 1982 removed the tax penalty for "grease" payments to minor government officials, ${ }^{7}$ and the Omnibus Trade and Competitiveness Act of 1988 made more important changes to provisions enacted by the FCPA. The 1988 Act changes the "reason to know" requirement of the FCPA to a standard of "knowing" that money is to be used for illegal purposes; in addition, the 1988 Act replaces the "grease" payment exception in the FCPA with an exception for "routine governmental actions." These changes have small practical significance, but do reflect ongoing concern over the impact of anti-bribery legislation on the competitiveness of American firms in foreign markets.

\section{Evidence.}

This section analyzes the behavior of US firms before and after passage of the Tax Reform Act of 1976 and the FCPA in 1977. The goal is to draw indirect inferences about the effect of this legislation on the volume of US business activity. Four aspects of US business performance are considered: patterns of FDI, capital/labor ratios, joint venture activity, and aircraft exports.

"It is noteworthy that American law prohibits this type of "grease" payment to government officials in the United States.

7This change was estimated to reduce US tax collections by $\$ 30$ million annually; see United States Congress, Joint Committee on Taxation (1982, p. 423). 


\subsection{Foreien Direct Investment.}

By imposing significant costs on firms and managers caught paying bribes, US

legislation effectively raises the cost of certain foreign business projects. One likely manifestation of a higher cost of doing business in corrupt foreign countries is a reduction in the volume of foreign direct investment (FDI) in these countries. ${ }^{8}$ One way to specify the impact of US anti-bribery legislation on business activity is the following:

$$
\mathrm{g}_{\mathrm{i}, \text { us }}=\alpha+\gamma_{\mathrm{i}}+\beta_{1} \text { Corrupt }_{i}+\mathrm{u}_{\mathrm{i}}
$$

in which $g_{i, \text { us }}$ is the post-1977 growth rate of US FDI in country $i, \alpha$ is a constant term, $\gamma_{i}$ represents the determinants of American FDI growth in country i that are unrelated to corruption, Corrupt is a measure of the degree to which it is necessary to pay bribes in order to do business successfully in country $i$, and $u_{i}$ is a residual assumed to be normally distributed with zero mean and finite variance. The goal of the estimation is to measure the value of $\beta_{1}$. Since $g_{i, u s}$ is a ratio of post-1977 US FDI to pre-1977 US FDI, it is not affected by factors (such as distance from the United States) that make certain locations always less desirable from the standpoint of American investors.

Since $\gamma_{\mathrm{i}}$ is unobservable it cannot be included directly in the estimation of equation (1), though certain observable variables may proxy reasonably well for $\gamma_{i}$. The following specification of $\gamma_{i}$ affords straightforward empirical implementation:

The amount by which anti-bribery legislation is likely to reduce US business activity in corrupt foreign countries depends on the structure of product markets, the abilities of foreign government officials to discriminate between foreign firms in setting their bribe demands, and other considerations. See Beck and Maher (1989) for a theoretical treatment of some of these issues. It is even possible for the US legislation to increase the volume of US business abroad, particularly so if foreign officials differentiate their bribe demands on the basis of nationality, and if US firms tend to compete against each other for foreign contracts. 


$$
\gamma_{i}=\beta_{2} \Delta G D P_{i}+\beta_{3} g_{i, f}+u_{i}^{\prime}
$$

in which $\Delta G P_{i}$ is the percentage change in country $i$ 's GDP over the sample period, $g_{i, t}$ is the growth rate of FDI (from all sources) into country $i, \beta_{2}$ and $\beta_{3}$ are unknown parameters, and $u_{i}^{\prime}$ is a normally distributed residual. This specification of $\gamma_{i}$ relies on the assumption that GDP and FDI growth rates are unaffected by US FDI, but reflect economic conditions that also influence the growth rate of US FDI. Combining (2) and (1) yields:

$$
\mathbf{g}_{i, u s}=\alpha+\beta_{1} \text { Corrupt }_{i}+\beta_{2} \Delta \text { GDP }_{i}+\beta_{3} g_{i, f}+\epsilon_{i}
$$

in which $\epsilon_{i}=\left(u_{i}+u_{i}{ }^{\prime}\right)$.

\section{Data}

The measurement of local corruption is of central importance to applying the regression model specified in (3). Data on country corruption levels are collected by Business International (BI), which is now part of the Economist Intelligence Unit. BI sells to international investors its assessments of political and regulatory aspects of doing business in foreign countries. BI reports 56 "country risk" factors for 68 countries covering the year 1980; one of these "country risk" factors is the level of official corruption. ${ }^{9}$ Specifically, BI assigns to each country an index corresponding to "the degree to which business transactions involve corruption or questionable payments." This corruption index is an integer ranging from zero (denoting "degree of corruption prohibitive for profitable business activity") to ten ("virtual absence of corruption in government and

'Paolo Mauro generously provided these data, having collected them by hand from BI's archival copies. Mauro (1995) contains a description and analysis of the data. Other FDI studies using the BI country risk data include Wheeler and Mody (1992). 
business"). ${ }^{10}$ This index reflects the assessments of Bl's local correspondents and analysts, and is subject to review by regional BI staff and central management.

Information on total foreign direct investment in each country is provided by the World Bank (1984, supplemented by earlier editions)." Data on the US foreign direct investment position is reported by the Bureau of Economic Analysis (BEA) of the US Department of Commerce. BEA reports stocks of US-controlled FDI, on an historical-cost basis, by country, for yearend 1977 and yearend 1982 . Denoting the US FDI stock in country $i$ at yearend 1977 by $S_{i, 19 m}$, and the same stock at yearend 1982 by $S_{i, 1922}$, the growth rate of US FDI from 1977-1982 is defined to be: $g_{i, u s}=\left(S_{i, 1962}-S_{i, 19 n}\right) / S_{i, 19 n}$

The World Bank provides information on annual flows of FDI, but it is not possible to obtain reliable information on total stocks of foreign direct investment in a large sample of countries. It is, however, possible to construct a partial "stock" by summing the annual flows of FDI over the period 1966-1977. Denoting the flow of FDI into country $i$ in year $t$ by $I_{\text {it }}$, the growth rate of FDI from 1977-1982 is defined to be:

$$
g_{i, f}=\frac{\sum_{t=1978}^{1962} I_{i t}}{\sum_{t=1966}^{197} I_{i t}}
$$

${ }^{10} \mathrm{BI}$ provides descriptions of the even-numbered corruption levels: level two corresponds to "widespread corruption, deeply ingrained;" level four to "corruption fairly rampant, though with occasional crackdowns;" level six to "facilitative payments occasionally necessary;" level eight to "small gifts or payments considered normal." These descriptions apply to general business conditions, not specifically those encountered only by foreign investors. The proprietary nature of the BI corruption numbers precludes any discussion in this paper of individual country rankings.

"Data on foreign direct investment are reported by host countries as part of their national income and product accounts; calculation methodologies differ somewhat between countries. See International Monetary Fund (1993) for a general description of the methodologies used. 
As a consequence, the measured growth rates of US FDI $\left(g_{i, u s}\right)$ and total FDI $\left(g_{i, \ell}\right)$ are not perfectly comparable, since $\mathrm{g}_{\mathrm{i}, \mathrm{us}}$ is measured with greater precision, and the definitional differences systematically reduce values of $g_{i, u s}$ relative to those of $g_{i, f}$. GDP information is contained in the data base described by Summers and Heston (1991). ${ }^{12}$

\section{Estimates}

There are 35 countries for which sufficient data are available to estimate equation (3).

Table 1 describes $\mathbf{g}_{\mathrm{i}, \text { us }}$ and $\mathbf{g}_{\mathrm{i}, \mathrm{f}}$ for country groups that are distinguished by degree of corruption and GDP growth rates. "Corrupt" countries are defined to be those with BI indices 0-7; "less-corrupt" countries are those with BI indices 8-10. High-growth countries have five-year real GDP growth [defined as $\left(\mathrm{GDP}_{x^{2}}-\mathrm{GDP}_{n}\right) / \mathrm{GDP}_{n}$ ] above the sample median. Of the ten "corrupt" countries in this sample, nine have high GDP growth.

The data described in Table 1 indicate that, from 1977-1982, total FDI into corrupt high-growth countries grew rapidly: the median $\mathrm{g}_{\mathrm{i}, \mathrm{f}}$ for this group is 1.38 . By contrast, the median $\mathbf{g}_{\mathrm{i}, \mathrm{f}}$ for less-corrupt high-growth countries is $\mathbf{0 . 8 8}$. FDI from the United States exhibits the opposite pattern: median $\mathrm{g}_{\mathrm{i}, u s}$ for corrupt high-growth countries is 0.80 , while median $\mathrm{g}_{\mathrm{i}, \mathrm{us}}$ for less-corrupt high-growth countries is 0.99 . These statistics suggest that US investors differed from others in preferring to locate their FDI in less-corrupt countries after 1977.

Columns 1 and 3 of Table 2 report estimates of (3) using a rescaling of BI's

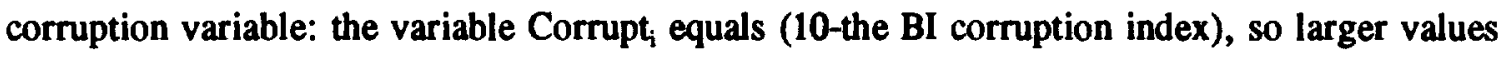
correspond to more corrupt countries. Columns 2 and 4 of Table 2 report estimates of (3) using instead a dummy variable equal to one if the BI corruption level is $\mathbf{0 - 7}$, and zero otherwise. The

\footnotetext{
${ }^{12}$ Appendix Table 1 presents means and standard deviations of the variables used in the regressions that follow.
} 
dummy variable specifications are valuable because they use only the ordinal properties of the BI corruption index. The regressions reported in columns 1 and 3 of Table 2 impose the restriction that the difference between corruption levels two and four has the same impact on post-1977 US FDI growth as does the difference between levels six and eight. The regressions reported in columns 2 and 4 impose an alternative restriction that effectively ignores small differences between the corruption levels of very-corrupt countries.

The estimates in column 1 of Table 2 indicate that American FDI grew more rapidly after 1977 in the less-corrupt countries than in the corrupt countries, after controlling for GDP growth and total FDI. The point estimate of the corruption coefficient indicates that a difference of two points in the BI index is associated with $100 \%$ faster growth of FDI from the United States. ${ }^{13}$ Since the regressions span a 5-year time period, this effect corresponds to roughly $20 \%$ per year. The mean growth rate of US FDI over this time span is 0.70 , or roughly $14 \%$ per year, so the estimated impact of local corruption is large relative to the mean. The coefficients on GDP growth and $\mathrm{g}_{i, f}$ have the expected positive signs, though the latter does not differ significantly from zero.

Another way to gauge the size of the corruption coefficient is to compare it to the estimated coefficient of 8.72 on $\% \Delta$ GDP. The estimated coefficients on corruption and on $\% \Delta$ GDP imply that a two point corruption level difference generates the same impact on US FDI as does an 11\% GDP change over the 5-year time period. Both are differences of approximately threequarters of a standard deviation in the respective variables.

The results reported in column 2 tell a similar story. The estimates imply that local corruption influenced FDI from the United States as much as did $31 \%$ differences in GDP growth

\footnotetext{
${ }^{13}$ In the data reported by Mauro (1995), a two point difference in the BI corruption index corresponds, for example, to the difference between Spain (less corrupt) and Panama (more corrupt). US FDI is measured at book values, so the dependent variable and the estimated coefficients are likely to be of greater magnitude than they would be if FDI were measured at market values.
} 
over the 5-year period.

The results presented in Table 2 suggest that American legislation discouraged American firms from investing in the more corrupt countries, though it is possible that US investment in these countries declined for reasons having nothing to do with corruption. For example, the corrupt countries tend to have smaller economies than do the less-corrupt countries, and US investors may have been attracted to wealthier economies over this time period, even relative to their own past behavior and the behavior of foreign investors. However, columns 3 and 4 report regressions that include a country's level of GDP as an explanatory variable; the results differ very little from those reported in columns 1 and $2 .^{14}$

\subsection{Capital-Labor Ratios.}

Firms subject to penalties for paying bribes may find that they can compensate local politicians by hiring additional workers in lieu of paying bribes. Their ability to substitute payroll for payoffs suggests that American firms might reduce their capital/labor ratios in the more corrupt countries after 1977. This section explores this possibility.

In earlier theoretical work, Shleifer and Vishny (1994) analyze a model in which government officials benefit from local investments in three ways: through the tax revenues investments generate, through the effects of investment on local employment, and through their ability to extract bribes from investors. In this setting, limitations on the abilities of firms to bribe politicians typically generate outcomes in which employment expands to compensate politicians in a legal manner. Consequently, the model implies that restrictions on the ability to pay bribes should

${ }^{14}$ The small sample size raises another possibility: that a few nonrepresentative outliers drive the results reported in Table 2. Minimum absolute deviation (MAD) estimators can be more robust than OLS estimators in these circumstances. Appendix Table 2 reports MAD estimates of the same coefficients; they resemble the OLS estimates reported in Table 2. Very similar results also appear when $\log ($ GDP) is used as an explanatory variable in place of GDP. 
reduce capital/labor ratios.

Data

BEA performs periodic comprehensive surveys of the foreign operations of American multinational corporations. BEA $(1975,1981,1985)$ reports data on annual labor compensation and gross book values of stocks of property, plant, and equipment (PPE) held abroad by American firms in 1966, 1977, and 1982. BEA reports aggregate figures for countries in which there is substantial US investment; to protect the confidentiality of survey responses, BEA suppresses information for countries in which one or two US firms represent large fractions of total US investment.

\section{Model and Estimates}

The goal of the estimation is to examine whether capital/labor ratios after 1977 appear to be affected by the US anti-bribery legislation. Since there is considerable cross-country variation in the capital/labor ratios of foreign investors, and much of this variation is due to national differences in real factor prices, industrial composition, and other stable aspects of economic life that have little to do with bribery, it is necessary to correct for underlying capital/labor ratios.

Table 3 describes differences between the growth rates of capital and labor compensation by US firms in different countries over the period 1977-1982. Of the 13 corrupt countries for which data on capital-labor ratios are available over this time period, 11 have abovemedian GDP growth. The first column of Table 3 reports that the median capital-labor ratio for this group of corrupt high-growth countries fell slightly between 1977 and 1982 . By contrast, columns 2 and 3 report that median capital-labor ratios of US affiliates in less-corrupt countries rose between 1977 and 1982, particularly for the high GDP-growth group. These simple statistics are consistent with the predicted impact of corruption on capital-labor ratios. 
Table 4 presents estimated coefficients from models in which differences between capital and labor growth rates are regressed on levels of corruption and changes in GDP. These specifications implicitly control for national differences in capital/labor ratios in 1977, and are unaffected by unobservable factors that influence levels of US investment without changing capital/labor ratios.

The estimates reported in column 1 of Table 4 are also consistent with the idea that anti-bribery legislation reduced capital/labor ratios in corrupt countries, though the estimated coefficient on the corruption variable is not significantly different from zero. Estimates of the model in which the corruption dummy variable is used in place of BI's corruption index, reported in column 2, offer stronger results. The estimates imply that differences between the growth of capital and labor employed by US-owned affiliates in more-corrupt countries fell by $87 \%$ relative to the same difference in less-corrupt countries. The estimates also suggest that the impact of corruption on capital/labor ratios is equal to the impact of a $31 \%$ difference in GDP growth over the five-year period, which is remarkably similar to the results of the FDI regressions reported in Table 2. The inclusion of 1977 GDP as an explanatory variable (reported in columns 3 and 4) increases the statistical significance of the estimated corruption coefficients without changing their interpretation. ${ }^{\text {is }}$

It is possible that the estimates reported in Table 4 reflect a long-term trend of falling capital/labor ratios in certain countries, and not the impact of US legislation. One way to test this alternative explanation is to examine the trend of US behavior in the period prior to 1977 . Table 5 reports the results of re-running the regressions reported in Table 4 using data for 1966-1977. Due to limited coverage in the 1966 BEA survey, only 28 countries are included in the sample. The results are disappointing from a statistical standpoint - none of the estimated coefficients differs significantly

\footnotetext{
${ }^{15}$ MAD estimates of the same equations (reported in Appendix Table 3) differ very little from the OLS estimates reported in Table 4.
} 
from zero - but the point estimates of the corruption coefficients take the opposite signs of those reported in Table 4. Any country-specific secular trends in capital/habor ratios that might be responsible for the results reported in Table 4 are not evident over the 1966-1977 period.

\subsection{Minority Ownership.}

One of the issues concerning US investors after passage of the FCPA was the possibility that US firms could be penalized for bribes paid by their foreign business partners. The Comptroller General's Report to Congress (1981, pp. 38-39) calls attention to this issue, noting that survey respondents worried that US law could be interpreted to mean that any American firm with business operations in countries in which bribery of government officials is commonplace might have "reason to know" that illegal bribery is taking place. Then if the business partners of these US firms pay bribes, the American partner could be liable for criminal penalties (including prison sentences) under US law.

The GAO report adds that some American firms report that they withdrew from joint ventures in foreign countries out of fear that they could be held responsible for the actions of their partners. The goal of this section is to examine whether there is evidence that US firms systematically avoided participation in joint ventures in corrupt countries after 1977.

\section{Data}

Unfortunately, there is very little direct evidence on US firms' participation in international joint ventures. BEA does, however, distinguish the activities of majority-owned foreign affiliates of US firms from the activities of all foreign affiliates of US firms. In particular, BEA reports amounts of PPE owned by all US affiliates and amounts of PPE owned by majority-owned US affiliates. The difference represents PPE held by affiliates in which American investors own between 
10 and 50 percent. 1977 is the first benchmark year in which BEA reports data separately for all affiliates and for majority-owned affiliates.

\section{Model and Estimates}

The distinction between the activities of all US affiliates and those of US majoritycontrolled affiliates affords an opportunity to use data on the behavior of majority-owned affiliates to control for unobservable variables that affect all US affiliates. Equations (1)-(3) describe a model in which FDI from other countries is used to control for unobserved factors that influence US FDI growth; the same type of treatment can be used to anlayze the effect of US legislation on minority ownership.

Table 6 presents descriptive statistics of US affiliates' PPE growth in corrupt and lesscorrupt countries between 1977 and 1982. As expected, growth rates of US PPE in high GDPgrowth countries far exceed PPE growth rates in low GDP-growth countries. ${ }^{16}$ Among the corrupt, high GDP-growth, countries, median PPE growth in majority-owned affiliates (1.41) exceeds median PPE growth in all affiliates (1.12). US affiliates in less-corrupt, high GDP-growth, countries exhibit the opposite pattern: in these countries, median PPE growth in majority-owned affiliates $(0.82)$ is smaller than median PPE growth in all affiliates (1.00). Hence, the fraction of total investment representing US minority ownership fell in corrupt countries and rose in less-corrupt countries, which is consistent with the GAO's assessment of the impact of US anti-bribery legislation.

Table 7 reports estimated coefficients from a model in which PPE accumulation by majority-owned affiliates is used to control for unobservables in an equation explaining PPE accumulation by all affiliates. The results in Table 7 indicate that US ownership of PPE in the more

${ }^{16} \mathrm{Hines}$ and Rice (1994) estimate that demand for PPE by US multinationals is roughly unit elastic with respect to GDP. 
corrupt countries fell after 1977, after controlling for GDP growth and changes in ownership of PPE by majority-owned US affiliates. Since minority-owned PPE is the difference between total US ownership of PPE and majority ownership of PPE, the results imply that US minority participation in business ventures in corrupt countries declined after 1977 .

The estimated coefficient on the corruption variable in column 1 of Table 7 does not differ significantly from zero, but the coefficient on the corruption dummy variable in column 2 is large and significant. The estimates reported in column 2 imply that the difference between corrupt and less-corrupt countries has the same impact on total PPE growth as do $100 \%$ differences of PPE accumulation by majority-owned affiliates, or 34\% differences in GDP growth, over the five-year period. Inclusion of 1977 GDP as an explanatory variable yields significant corruption effects (reported in columns 3 and 4) that are similar to those reported in columns 1 and $2 .{ }^{17}$

\subsection{Aircraft Exports.}

The impact of US anti-bribery legislation on exports from the United States is likely to vary between industries with the degree to which bribes are customarily paid. Official US government publications identify the exports of two industries, aircraft and construction, as the most likely to be negatively impacted by US anti-bribery legislation." It is not difficult to understand why bribery is particularly important to exports in these two industries. Individual aircraft and construction contracts tend to be sizable, making a contract's value to a supplier large relative to bribes that are necessary to influence government decisionmakers. Another factor influencing bribery

\footnotetext{
${ }^{17}$ MAD estimates of the same equations (reported in Appendix Table 4) differ very little from the OLS estimates reported in Table 7.

${ }^{18}$ See, for example, Comptroller General of the United States (1981, p. ii).
} 
in these industries is imperfect competition. ${ }^{19}$ Equilibrium in the bribery market is likely to be characterized by greater bribes in less-competitive industries, since producer surplus is higher in these industries. ${ }^{20}$ This section measures differences between the changes in US aircraft export performance in corrupt and less-corrupt countries after 1977 , while controlling for general changes in US exports to those countries. This approach has the advantage of removing the effect of countryspecific factors (such as exchange rate movements) that influence all exports in roughly the same way.

Data

Information on annual imports and exports are reported by the United Nations (various issues). These data distinguish imports by source country and by commodity classification. Imports for the two years 1976 and 1977 are summed to construct US import shares for the period immediately prior to passage of the US anti-bribery legislation, while data for 1981 and 1982 are summed to construct import shares for the period following enactment of the legislation. ${ }^{21}$

\section{Model and Estimates}

The data described in Table 8 indicate that US aircraft exports fell as a fraction of the world market over the period 1976/77-1981/82. The median decline of US import shares among corrupt countries (21.2\%) was far more pronounced than that among less-corrupt countries (6.4\%). Since this difference could reflect the impact of many economic factors, it is instructive to contrast it

\footnotetext{
${ }^{19}$ See, for example, Baldwin and Krugman (1988) on imperfect competition in the world aircraft industry.

${ }^{20}$ Rose-Ackerman (1975, 1978), Beck and Maher (1989), and Shleifer and Vishny (1993, 1994) analyze the determinants of bribe levels.

${ }^{21}$ Two-year periods are used in order to reduce the sensitivity of the results to short-term fluctuations. Aircraft data appear as Commodity Trade Classification 734, which includes fixed-wing military aircraft.
} 
to the performance of all US exports. Table 8 indicates that US exports rose slightly over this period, with very little difference between the median change in US import shares in corrupt countries (0.72\%) and that in less-corrupt countries $(0.68 \%)$. These figures suggest that whatever is responsible for the large relative decline in US aircraft exports to corrupt countries after 1977 did not influence all US exports in the same way.

Table 9 reports estimates of a model in which the change in the US share of a country's aircraft imports is regressed on the change in the share of total imports from the United States and on the local corruption level. The estimates suggest that US aircraft exports to the more corrupt countries fell significantly after 1977 after controlling for changes in the share of all US exports. The estimates in column 1 imply that a difference of two corruption levels changes the US share of aircraft exports by $4 \%$ after 1977 , which is the same effect that would be generated by a $2 \%$ change in the US share of all imports. Similar results appear in columns 2-4 of Table 9, and in Appendix Table 5, which presents MAD estimates of the same equations.

It is worth emphasizing that the corruption results reported in Table 9 pertain to differences between import shares of US aircraft and of all US commodities. The estimates do not indicate the overall impact of US legislation on changes in aircraft sales after 1977. To the extent that US anti-bribery laws had a chilling effect on all exports, the figures in Table 9 understate their overall effect on aircraft sales.

There remains the possibility that the results reported in Table 9 simply reflect trends in the aircraft market that happen to coincide with corruption. One way to distinguish this possibility from the interpretation that US legislation reduced aircraft exports in more corrupt countries is to examine changes in import shares during the period prior to 1977 . Table 10 repeats the regressions reported in Table 9, but uses data for the time period 1971/72 - 1976/77. The coefficients on the corruption variables reported in Table 10 are statistically insignificant and take the opposite signs of 
the corresponding coefficients reported in Table 9, suggesting that there is no obvious secular trend that explains the results reported in Table 9.

\section{Interpretation.}

This paper examines four dimensions of the behavior of US firms after 1977, and in all four, there appears to be a significant effect of US anti-bribery legislation on business operations in corrupt countries. These results are consistent with numerous accounts of the impact of US legislation on the ways in which American firms conduct their overseas business, ${ }^{2}$ and challenge the received wisdom of the academic literature that the Foreign Corrupt Practices Act of 1977 had no impact on US competitiveness in foreign markets. ${ }^{20}$

The apparent relative decline of American business activity in the more-corrupt countries after 1977 does not necessarily imply that US legislation reduced total levels of foreign business activity, or even bribe payments by foreign multinationals, in these countries. The reason is that foreign firms may simply have replaced American firms in the more bribery-intensive activities in

${ }^{22}$ In the Comptroller General's (1981) survey of 250 firms in the Fortune 1000, 30\% of the respondents report a reduction in overseas business as a consequence of the FCPA; the figure is over 50\% among firms in the aircraft and construction industries. Prasad's (1993) later survey of US exporters yields similar results: $44 \%$ of the 336 respondents report that the FCPA is responsible for "moderate" to "very great" reductions in their exports. In the Carter administration's survey, 19 of 45 US embassies responding indicated that the FCPA reduces US exports to their countries (US President, 1980).

${ }^{25}$ Earlier studies that find US anti-bribery legislation not to influence the offshore business activities of US firms face design issues that may influence their conclusions. Graham (1984) examines post-1977 changes in shares of US exports to more-corrupt and less-corrupt countries, finding no significant difference between the country groups. But this study fails to control for other variables that influence foreign trade, thereby reducing the power of the test. Beck, Maher, and Tschoegl (1991) argue that Latin America, as a whole, is particularly corrupt, and draw their conclusion that the US anti-bribery legislation was ineffective from evidence that the total US share of Latin American imports rose after 1977. This study treats Latin American countries (some of which receive corruption ratings of 10 from Business International) in a rather unnuanced fashion, and shares the Graham study's limitation of not controlling for unobservables. Gillespie (1987) argues that the FCPA did not significantly reduce US business activity in Middle Eastern countries, since much of the post-1977 decline in US export shares in the region can be explained by other events; but this analysis also fails to control for other factors that affect US exports during that period. 
these countries, either by acquiring US operations or through the withdrawal of US firms from the market. US legislation in 1976 and 1977 changed the relative attractiveness of more-corrupt and lesscorrupt locations for US investors, thereby encouraging ownership substitution between American and foreign investors. ${ }^{24}$

There remains the question of to what extent anti-bribery legislation is consistent with US interests, and this question cannot be answered simply by calculating the impact of the legislation on business activities. There are, however, certain aspects of US policy that have clearly failed. The Carter and subsequent administrations attempted to use US legislation as a model for multilateral agreements to outlaw bribery of government officials. ${ }^{25}$ In spite of agreements among member countries of the UN, OAS, and OECD codemning bribery and recommending national legislation to outlaw foreign bribery, the United States is still the only country in the world to punish foreign bribery with legislation like the FCPA.

When the Ford Administration first proposed US legislation concerning bribe payments by American multinational firms, its plan was to require publicly-held American firms to disclose their bribe payments. By the time that the FCPA was signed by President Carter in December 1977, it contained criminal penalties for foreign bribery. Disclosure requirements and criminalization represent two approaches to the design of anti-bribery legislation; other possibilities include the use of aggressive "trigger" provisions that take effect only when other countries enact similar anti-bribery laws. One of the considerations in choosing between different methods of discouraging bribery is whether the law is intended to reduce bribe payments by American firms, or

${ }^{24}$ There is no clear evidence that US anti-bribery laws influenced total business operations in corrupt
countries. Appendix Tables 6 and 7 present estimates of total FDI and total aircraft import shares for
corrupt and less-corrupt countries; while the equations fit poorly, it is noteworthy that local corruption
has an insignificant effect on post-1977 growth of FDI and post-1977 changes in aircraft import shares.

${ }^{25}$ See, for example, US President (1980, p. 10). 
whether it is intended to reduce total bribe payments. The evidence in this paper suggests that US law has been at least partly successful at achieving the former goal, ${ }^{20}$ while not obviously successful at achieving the latter.

In amending the FCPA in 1988 to expand the range of permissible "grease payments," and to raise the standards of proof of malfeasance by US firms, Congress retreated from some of the principles and rhetoric that accompanied its unanimous passage of the FCPA in 1977. In the absence of effective multilateral prohibitions, the question still facing Congress is how best to strike a balance between the benefits of encouraging ethical behavior and the costs of social responsibility in one country.

${ }^{26}$ American legislation has not eliminated foreign bribery by American multinationals, as the post1977 record of prosecutions indicates. For example, Lockheed plead guilty in 1995 to charges of bribing a member of the Egyptian parliament in 1988 (New York Times, 1995), and numerous other cases are summarized in Prasad (1993). Longenecker, McKinney and Moore's (1988) survey of 2,219 US business executives finds that slightly fewer than half (48.7\%) consider foreign bribery to be ethically unacceptable, suggesting that many American firms would be willing to pay bribes if the benefits exceed the costs. 


\section{References}

Baldwin, Richard and Paul Krugman, 1988, "Industrial Policy and International Competition in WideBodied Jet Aircraft," in Robert E. Baldwin ed., Trade Policy Issues and Empirical Analysis, Chicago: University of Chicago Press, 45-71.

Beck, Paul J. and Michael W. Maher, 1989, "Competition, Regulation, and Bribery," Managerial and Decision Economics, 10, 1-12.

Beck, Paul J., Michael W. Maher, and Adrian E. Tschoegl, 1991, "The Impact of the Foreign Corrupt Practices Act on US Exports," Managerial and Decision Economics, 12, 295-303.

Blumenthal, W. Michael, 1977, "Statement before the Senate Committee on Banking, Housing, and Urban Affairs," in Foreign Corrupt Practices and Domestic and Foreign Investment Disclosure, Hearing before the Committee on Banking, Housing, and Urban Affairs, United States Senate, March 16, Washington, D.C.: US Government Printing Office, 67-74.

Comptroller General of the United States, 1981, Impact of Foreign Corrupt Practices Act On U.S. Business, Report to the Congress of the United States, Washington, D.C.: U.S. General Accounting Office.

Gillespie, Kate, 1987, "Middle East Response to the U.S. Foreign Corrupt Practices Act," California Management Review, 29, 9-30.

Graham, John L., 1984, "The Foreign Corrupt Practices Act: A New Perspective," Journal of International Business Studies, 15, 107-121.

Hines, James R., Jr. and Eric M. Rice, 1994, "Fiscal Paradise: Foreign Tax Havens and American Business," Quarterly Journal of Economics, 109, 149-182.

International Monetary Fund, 1993, Balance of Payments Manual, Washington, D.C.: International Monetary Fund.

Longenecker, Justin G., Joseph A. McKinney, and Carlos W. Moore, 1988, "The Ethical Issue of International Bribery: A Study of Attitudes Among U.S. Business Professionals," Journal of Business Ethics, 7, 341-346.

Mauro, Paolo, 1995, "Corruption and Growth," Quarterly Jourmal of Economies, 110, 681-712.

New York Times, 1995, "\$24.8 Million Penalty Paid By Lockheed," January 28, 144, 35.

Prasad, Jyoti N., 1993, Impact of the Foreign Corrupt Practices Act of 1977 on U.S. Export, New York: Garland.

Richardson, J. David, 1993, Sizing up U.S. Export Disincentives, Washington, D.C.: Institute for International Economics. 
Rose-Ackerman, Susan, 1975, "The Economics of Corruption," Journal of Public Economics, 4, 187-203.

Rose-Ackerman, Susan, 1978, Corruption: A Study in Political Economy, New York: Academic Press.

Shleifer, Andrei and Robert W. Vishny, 1993, "Corruption," Quarterly Journal of Economics, 108, 599-617.

Shleifer, Andrei and Robert W. Vishny, 1994, "Politicians and Firms," Quarterly Journal of Economics, 109, 995-1025.

Smith, David B., Howard Stettler, and William Beedles, 1984, "An Investigation of the Information Content of Foreign Sensitive Payment Disclosures," Journal of Accounting and Economics, 6, 153162.

Summers, Robert and Alan Heston, 1991, "The Penn World Table (Mark 5): An Expanded Set of International Comparisons, 1950-1988," Quarterly Journal of Economics, 106, 327-368.

United Nations, Commodity Trade Statistics, various issues, New York: United Nations.

United States Congress, Joint Committee on Taxation, 1982, General Explanation of the Revenue Provisions of the Tax Equity and Fiscal Responsibility Act of 1982, Washington, D.C.: U.S. Government Printing Office.

United States Department of Commerce, Bureau of Economic Analysis, 1975, U.S. Direct Investment Abroad, 1966: Final Data, Washington, D.C.: U.S. Government Printing Office.

United States Department of Commerce, Bureau of Economic Analysis, 1981, U.S. Direct Investment Abroad, 1977, Washington, D.C.: U.S. Government Printing Office.

United States Department of Commerce, Bureau of Economic Analysis, 1985, U.S. Direct Investment Abroad: 1982 Benchmark Survey Data, Washington, D.C.: U.S. Government Printing Office.

United States Senate, 1981, Business Accounting and Foreign Trade Simplification Act, Joint Hearings before the Subcommittee on Securities and the Subcommittee on International Finance and Monetary Policy of the Committee on Banking, Housing, and Urban Affairs, May 20 and 21, June 16, July 23 and 24, Washington, D.C.: U.S. Government Printing Office.

United States President, 1980, Report of the President on Export Promotion Functions and Potential Export Disincentives, Washington, D.C.: U.S. Government Printing Office.

Wheeler, David and Ashoka Mody, 1992, "International Investment Location Decisions: The Case of U.S. Firms," Journal of International Economics, 33, 57-76.

World Bank, 1984, World Tables, 3rd ed., vol. 1, Washington, D.C.: World Bank. 
Table 1

Foreign Direct Investment Trends, 1977-1982

Corrupt countries, Less-corrupt countries, Less-corrupt countries, high GDP growth high GDP growth low GDP growth

$\begin{array}{lcccc}\begin{array}{l}\text { \% } \Delta \text { FDI from } \\ \text { United States, } \\ \text { 1977-1982 }\end{array} & \text { median } & 0.7969 & 0.9937 & 0.4418 \\ & \begin{array}{c}\text { mean } \\ \text { (std. dev.) }\end{array} & \begin{array}{c}1.1408 \\ (0.6139)\end{array} & \begin{array}{c}0.8149 \\ (0.3851)\end{array} & 0.3962 \\ & & & & \\ & & & & \\ & & & & \\ \text { \% } \Delta \text { FDI from } & \text { median } & 1.3758 & 0.8841 & 0.8966 \\ \begin{array}{l}\text { all countries, } \\ 1977-1982\end{array} & \begin{array}{c}\text { mean } \\ \text { (std. dev.) }\end{array} & \begin{array}{c}1.6242 \\ (1.4880)\end{array} & 0.8310 & 1.2333 \\ & & (1.9051) & (2.1784)\end{array}$

No. countries

9

9

16

Note: "\% $\Delta$ FDI from United States" is the ratio of US FDI, 1978-1982, to the US FDI stock at yearend 1977. "\% $\triangle$ FDI from all countries" is the ratio of total foreign direct investment, 19781982, to the "stock" of FDI from all countries yearend 1977. Corrupt countries are those for which the BI corruption index for 1980 is $0-7$; less-corrupt countries are those for which the BI index is 810. High GDP growth countries are those with five-year real GDP growth exceeding the sample median (12.2\%) over 1977-1982. 
Table 2

US Foreign Direct Investment after 1977

Dependent Variable: US FDI, 1978-1982/US FDI Stock at Yearend 1977

\begin{tabular}{|c|c|c|c|c|}
\hline Constant & $\begin{array}{l}-0.4466 \\
(0.6742)\end{array}$ & $\begin{array}{l}-0.9728 \\
(0.6310)\end{array}$ & $\begin{array}{l}-0.4190 \\
(0.7606)\end{array}$ & $\begin{array}{c}-0.7575 \\
(0.6934)\end{array}$ \\
\hline $\begin{array}{l}\text { GDP, } 1977 \\
(\$ 100 \text { b) }\end{array}$ & & & $\begin{array}{l}-0.0105 \\
(0.1257)\end{array}$ & $\begin{array}{l}-0.0935 \\
(0.1210)\end{array}$ \\
\hline$\% \Delta$ GDP & $\begin{array}{c}8.7195 \\
(3.2331)\end{array}$ & $\begin{array}{c}12.5544 \\
(3.5132)\end{array}$ & $\begin{array}{c}8.7272 \\
(3.2874)\end{array}$ & $\begin{array}{l}13.0323 \\
(3.5898)\end{array}$ \\
\hline $\begin{array}{l}\% \Delta \mathrm{FDI}, \\
\text { all countries }\end{array}$ & $\begin{array}{c}0.2160 \\
(0.2233)\end{array}$ & $\begin{array}{c}0.2294 \\
(0.2089)\end{array}$ & $\begin{array}{c}0.2156 \\
(0.2271)\end{array}$ & $\begin{array}{c}0.2289 \\
(0.2103)\end{array}$ \\
\hline Corruption Level & $\begin{array}{l}-0.4813 \\
(0.1981)\end{array}$ & & $\begin{array}{c}-0.4834 \\
(0.2029)\end{array}$ & \\
\hline Corruption Dummy & & $\begin{array}{l}-3.8973 \\
(1.1702)\end{array}$ & & $\begin{array}{l}-4.1778 \\
(1.2324)\end{array}$ \\
\hline Adj. $\mathbf{R}^{2}$ & .155 & .259 & .127 & .249 \\
\hline No. obs. & 35 & 35 & 35 & 35 \\
\hline
\end{tabular}

Note: The dependent variable is the ratio of US FDI, 1978-1982, to the US FDI stock at yearend 1977. The variable " $\% \Delta$ FDI, all countries" is the ratio of total foreign direct investment, 19781982, to the "stock" of FDI from all countries at yearend 1977. The variable "Corruption Level" is (10-the BI corruption index); larger numbers correspond to greater degrees to which business transactions involve corruption or questionable payments in 1980 . The Corruption Dummy variable equals 1 if the BI corruption index is 0-7 (more corrupt countries), and is zero otherwise. The columns report estimated OLS coefficients; standard errors are in parentheses. 
Table 3

Capital-Labor Ratio Trends, 1977-1982

Corrupt countries, Less-corrupt countries, Less-corrupt countries, high GDP growth high GDP growth low GDP growth

$\begin{array}{lcccc}\text { \% } \triangle \text { PPE - } & \text { median } & -0.0312 & 0.5320 & 0.0939 \\ \text { \% } \Delta \text { Labor, } & & & & \\ 1977-1982 & \text { mean } & 0.0581 & 0.4947 & 0.3809 \\ & \text { (std. dev.) } & (0.6385) & (1.2858) & (0.7178)\end{array}$

No. countries

11

10

18

Note: "\% $\Delta$ PPE - \% $\Delta$ Labor" is the difference between the growth rate of US affiliates' property, plant, and equipment between 1977 and 1982, and the growth rate of their labor expenditures over the same period. Corrupt countries are those for which the BI corruption index for 1980 is 0-7; lesscorrupt countries are those for which the BI index is 8-10. High GDP growth countries are those with five-year real GDP growth exceeding the sample median (14.7\%) over 1977-1982. 
Dependent Variable: \% Change in PPE - \% Change in Labor, 1977-1982

$\begin{array}{lcccc}\text { Constant } & 0.0850 & 0.3621 & 0.1826 & 0.1857 \\ & (0.2001) & (0.1774) & (0.2400) & (0.2116) \\ \text { GDP, } 1977 & & & -0.0449 & -0.0715 \\ (\$ 100 \text { b) } & & & (0.0602) & (0.0563) \\ & & & \\ \text { \% } \Delta \text { GDP } & 2.2889 & 2.7849 & 2.2546 & 2.7778 \\ & (0.8045) & (0.7757) & (0.8106) & (0.7695) \\ & & & & \\ \text { Corruption Level } & -0.1037 & & -0.1108 & \\ & (0.0543) & & (0.0554) & \\ \text { Corruption Dummy } & & & & -0.9618 \\ & & -0.8723 & & (0.2840)\end{array}$

Adj. $\mathbf{R}^{2}$

No. obs.

Note: The dependent variable is the difference between the growth rate of US affiliates' property, plant, and equipment between 1977 and 1982, and the growth rate of their labor expenditures over the same period. The variable "Corruption Level" is (10-the BI corruption index); larger numbers correspond to greater degrees to which business transactions involve corruption or questionable payments in 1980. The Corruption Dummy variable equals 1 if the BI corruption index is 0-7 (more corrupt countries), and is zero otherwise. The columns report estimated OLS coefficients; standard errors are in parentheses. 


\begin{tabular}{|c|c|c|c|c|}
\hline Constant & $\begin{array}{c}0.7394 \\
(1.8950)\end{array}$ & $\begin{array}{c}0.7315 \\
(1.8897)\end{array}$ & $\begin{array}{c}2.5748 \\
(2.0545)\end{array}$ & $\begin{array}{c}2.5719 \\
(2.0586)\end{array}$ \\
\hline $\begin{array}{l}\text { GDP, } 1966 \\
(\$ \text { b) }\end{array}$ & & & $\begin{array}{l}-0.0116 \\
(0.0062)\end{array}$ & $\begin{array}{c}-0.0117 \\
(0.0063)\end{array}$ \\
\hline$\% \Delta \mathrm{GDP}$ & $\begin{array}{l}-5.2077 \\
(2.8191)\end{array}$ & $\begin{array}{l}-5.0650 \\
(2.5727)\end{array}$ & $\begin{array}{l}-5.0687 \\
(2.6882)\end{array}$ & $\begin{array}{l}-4.9043 \\
(2.4572)\end{array}$ \\
\hline Corruption Level & $\begin{array}{c}0.2231 \\
(0.5154)\end{array}$ & & $\begin{array}{c}0.0610 \\
(0.4988)\end{array}$ & \\
\hline Corruption Dummy & & $\begin{array}{c}1.1237 \\
(2.2896)\end{array}$ & & $\begin{array}{c}0.0466 \\
(2.2612)\end{array}$ \\
\hline Adj. $R^{2}$ & .069 & .071 & .154 & .153 \\
\hline No. obs. & 28 & 28 & 28 & 28 \\
\hline
\end{tabular}

Note: The dependent variable is the difference between the growth rate of US affiliates' property, plant, and equipment between 1966 and 1977, and the growth rate of their labor expenditures over the same period. The variable "Corruption Level" is (10-the BI corruption index); larger numbers correspond to greater degrees to which business transactions involve corruption or questionable payments in 1980. The Corruption Dummy variable equals 1 if the BI corruption index is 0-7 (more corrupt countries), and is zero otherwise. The columns report estimated OLS coefficients; standard errors are in parentheses. 
Table 6

Trends in Ownership of US Foreign Amliates, 1977-1982

Corrupt countries, Less-corrupt countries, Less-corrupt countries, high GDP growth high GDP growth low GDP growth

\begin{tabular}{|c|c|c|c|c|}
\hline $\begin{array}{l}\% \Delta \text { USA PPE, } \\
\text { all affiliates, } \\
1977-1982\end{array}$ & $\begin{array}{c}\text { median } \\
\text { mean } \\
\text { (std. dev.) }\end{array}$ & $\begin{array}{c}1.0581 \\
(0.5282)\end{array}$ & $\begin{array}{c}1.2825 \\
(1.2354)\end{array}$ & $\begin{array}{c}0.4760 \\
\\
0.8365 \\
(0.9765)\end{array}$ \\
\hline $\begin{array}{l}\% \Delta \text { USA PPE, } \\
\text { majority owned, } \\
1977-1982\end{array}$ & $\begin{array}{c}\text { median } \\
\text { mean } \\
\text { (std. dev.) }\end{array}$ & $\begin{array}{c}1.4074 \\
1.5311 \\
(0.8306)\end{array}$ & $\begin{array}{c}1.1774 \\
(1.2194)\end{array}$ & $\begin{array}{c}0.6204 \\
\\
0.8003 \\
(0.9289)\end{array}$ \\
\hline
\end{tabular}

No. countries

Note: "\% $\triangle$ USA PPE, all affiliates" is the growth rate of US affiliates' property, plant, and equipment (PPE) between 1977-1982; "\% $\triangle$ USA PPE, majority-owned" is the growth rate of US majority-owned affiliates' PPE over the same period. Corrupt countries are those for which the BI corruption index for 1980 is 0-7; less-corrupt countries are those for which the Bl index is 8-10. High GDP growth countries are those with five-year real GDP growth exceeding the sample median (14.7\%) over 1977-1982. 
Table 7

Minority US Ownership of Foreign Affiliates after 1977

Dependent Variable: \% change in local PPE, all affiliates, 1977-1982

\begin{tabular}{|c|c|c|c|c|}
\hline Constant & $\begin{array}{c}0.2722 \\
(0.1675)\end{array}$ & $\begin{array}{c}0.2278 \\
(0.1576)\end{array}$ & $\begin{array}{c}0.3635 \\
(0.2074)\end{array}$ & $\begin{array}{c}0.3594 \\
(0.1966)\end{array}$ \\
\hline $\begin{array}{l}\text { GDP, } 1977 \\
(\$ 100 \text { b) }\end{array}$ & & & $\begin{array}{l}-0.0373 \\
(0.0494)\end{array}$ & $\begin{array}{c}-0.0546 \\
(0.0490)\end{array}$ \\
\hline$\% \Delta$ GDP & $\begin{array}{c}1.3317 \\
(0.7418)\end{array}$ & $\begin{array}{c}1.6153 \\
(0.7556)\end{array}$ & $\begin{array}{c}1.3777 \\
(0.7486)\end{array}$ & $\begin{array}{c}1.7344 \\
(0.7607)\end{array}$ \\
\hline $\begin{array}{l}\% \triangle P P E \\
\text { majority owned }\end{array}$ & $\begin{array}{c}0.6048 \\
(0.1192)\end{array}$ & $\begin{array}{c}0.5823 \\
(0.1167)\end{array}$ & $\begin{array}{c}0.5813 \\
(0.1239)\end{array}$ & $\begin{array}{c}0.5452 \\
(0.1210)\end{array}$ \\
\hline Corruption Level & $\begin{array}{l}-0.0843 \\
(0.0431)\end{array}$ & & $\begin{array}{l}-0.0898 \\
(0.0440)\end{array}$ & \\
\hline Corruption Dummy & & $\begin{array}{l}-0.5482 \\
(0.2314)\end{array}$ & & $\begin{array}{l}-0.6201 \\
(0.2395)\end{array}$ \\
\hline Adj. $\mathbf{R}^{2}$ & .548 & .567 & .543 & .570 \\
\hline No. obs. & 41 & 41 & 41 & 41 \\
\hline
\end{tabular}

Note: The dependent variable is the growth rate of US affiliates' property, plant, and equipment (PPE) between 1977-1982. The variable "\% $\triangle$ PPE, majority-owned" is the growth rate of US majority-owned affiliates' PPE over the same period. The variable "Corruption Level" is (10-the BI corruption index); larger numbers correspond to greater degrees to which business transactions involve corruption or questionable payments in 1980 . The Corruption Dummy variable equals 1 if the BI corruption index is $0-7$ (more corrupt countries), and is zero otherwise. The columns report estimated OLS coefficients; standard errors are in parentheses. 
Table 8

Aircraft Import Trends, 1976/77-1981/82

Corrupt countries Less-corrupt countries

$\Delta \%$ aircraft

median

$-0.2118$

$-0.0637$

imports from

United States,

mean

$-0.1693$

$-0.0150$

1976/77-1981/82

(std. dev.)

$(0.2860)$

(0.2778)

$\Delta \%$ all commodity imports from

United States, 1976/77-1981/82

\author{
median \\ mean \\ (std. dev.)
}

0.0072

0.0068

0.0093

$(0.0371)$

0.0068

$(0.0312)$

No. countries

Note: " $\Delta \%$ aircraft imports from United States" is the difference between the US share of aircraft imports in 1981/82 and the same share in 1976/77. " $\Delta \%$ all commodity imports from United States" is the difference between the US share of a country's imports of all goods in 1981/82 and the same share in 1976/77. Corrupt countries are those for which the BI corruption index for 1980 is $0-7$; less-corrupt countries are those for which the BI index is 8-10. 
Table 9

US Aircraft Exports after 1977

Dependent Variable: (US share of aircraft imports 1981/82 - US share 1976/77)

\begin{tabular}{|c|c|c|c|c|}
\hline Constant & $\begin{array}{l}-0.0008 \\
(0.0590)\end{array}$ & $\begin{array}{l}-0.0296 \\
(0.0536)\end{array}$ & $\begin{array}{c}0.0561 \\
(0.0703)\end{array}$ & $\begin{array}{c}0.0328 \\
(0.0665)\end{array}$ \\
\hline $\begin{array}{l}\text { GDP, } 1977 \\
(\$ 100 \text { b) }\end{array}$ & & & $\begin{array}{l}-0.0281 \\
(0.0194)\end{array}$ & $\begin{array}{c}-0.0310 \\
(0.0202)\end{array}$ \\
\hline $\begin{array}{l}\Delta \text { US Share } \\
\text { Total Imports }\end{array}$ & $\begin{array}{c}2.1295 \\
(1.2825)\end{array}$ & $\begin{array}{c}2.1551 \\
(1.3010)\end{array}$ & $\begin{array}{c}2.2727 \\
(1.2689)\end{array}$ & $\begin{array}{c}2.3275 \\
(1.2837)\end{array}$ \\
\hline Corruption Level & $\begin{array}{l}-0.0360 \\
(0.0171)\end{array}$ & & $\begin{array}{l}-0.0428 \\
(0.0175)\end{array}$ & \\
\hline Corruption Dummy & & $\begin{array}{l}-0.1597 \\
(0.0886)\end{array}$ & & $\begin{array}{l}-0.2094 \\
(0.0929)\end{array}$ \\
\hline Adj. $\mathbf{R}^{2}$ & .110 & .085 & .134 & .116 \\
\hline No. obs. & 42 & 42 & 42 & 42 \\
\hline
\end{tabular}

Note: The dependent variable is the difference between the US share of aircraft imports in 1981/82 and the same share in 1976/77. The variable " $\Delta$ US Share Total Imports" is the difference between the US share of a country's imports of all goods in 1981/82 and the same share in 1976/77. The variable "Corruption Level" is (10-the BI corruption index); larger numbers correspond to greater degrees to which business transactions involve corruption or questionable payments in 1980 . The Corruption Dummy variable equals 1 if the BI corruption index is 0-7 (more corrupt countries), and is zero otherwise. The columns report estimated OLS coefficients; standard errors are in parentheses. 
Dependent Variable: (US share of aircraft imports 1976/77 - US share 1971/72)

\begin{tabular}{|c|c|c|c|c|}
\hline Constant & $\begin{array}{c}-0.0144 \\
(0.0536)\end{array}$ & $\begin{array}{l}-0.0061 \\
(0.0477)\end{array}$ & $\begin{array}{c}0.0078 \\
(0.0659)\end{array}$ & $\begin{array}{c}0.0088 \\
(0.0603)\end{array}$ \\
\hline $\begin{array}{l}\text { GDP, } 1972 \\
(\$ 100 \mathrm{~b})\end{array}$ & & & $\begin{array}{l}-0.0131 \\
(0.0223)\end{array}$ & $\begin{array}{l}-0.0093 \\
(0.0225)\end{array}$ \\
\hline $\begin{array}{l}\Delta \text { US Share } \\
\text { Total Imports }\end{array}$ & $\begin{array}{c}2.2718 \\
(1.1433)\end{array}$ & $\begin{array}{c}2.1594 \\
(1.1186)\end{array}$ & $\begin{array}{c}2.0439 \\
(1.2174)\end{array}$ & $\begin{array}{c}2.0075 \\
(1.1900)\end{array}$ \\
\hline Corruption Level & $\begin{array}{c}0.0275 \\
(0.0171)\end{array}$ & & $\begin{array}{c}0.0241 \\
(0.0182)\end{array}$ & \\
\hline Corruption Dummy & & $\begin{array}{c}0.1647 \\
(0.0865)\end{array}$ & & $\begin{array}{c}0.1505 \\
(0.0940)\end{array}$ \\
\hline Adj. $\mathbf{R}^{2}$ & .091 & .116 & .074 & .094 \\
\hline No. obs. & 38 & 38 & 38 & 38 \\
\hline
\end{tabular}

Note: The dependent variable is the difference between the US share of aircraft imports in 1976/77 and the same share in 1971/72. The variable " $\Delta$ US Share Total Imports" is the difference between the US share of a country's imports of all goods in 1976/77 and the same share in 1971/72. The variable "Corruption Level" is (10-the BI corruption index); larger numbers correspond to greater degrees to which business transactions involve corruption or questionable payments in 1980 . The Corruption Dummy variable equals 1 if the BI corruption index is 0-7 (more corrupt countries), and is zero otherwise. The columns report estimated OLS coefficients; standard errors are in parentheses. 
Appendix Table 1

Variable Means and Standard Deviations

$\begin{array}{llll}\text { Variable } & \text { Mean } & \text { Standard Deviation } & \text { No. Obs. }\end{array}$

US FDI, 1978-1982/

0.70412

0.53534

35

US FDI Stock at Yearend 1977

\% $\Delta$ FDI, all countries

1.23027

1.91293

35

GDP, 1977

1.48345

2.23576

42

( $\$ 100$ billion)

Corruption level

2.38095

2.47871

42

Corruption dummy

0.35714

0.48497

42

\% $\Delta$ GDP, 1977-1982

0.18685

0.16845

41

$\% \Delta$ PPE - \% $\Delta$ labor,

0.27996

0.86848

41

1977-1982

\% $\Delta$ PPE, 1977-82

0.97681

0.94616

41

\% $\triangle$ PPE, majority-owned,

1.06632

1.00465

41 1977-82

$-0.07007$

0.28721

42

imports, 1976/77-1981/82

0.00770

0.03301

42

Note: The variables represent country-level aggregate activities of US and foreign investors. US FDI data are reported by BEA; total FDI data are reported by the World Bank. The GDP variables are based on Summers-Heston calculations. Corruption data are described in Mauro (1995); the "corruption level" variable equals (10-the BI corruption index); the "corruption dummy" variable equals 1 if "corruption level" is greater than 2, and is zero otherwise. BEA reports US affiliates' stocks of PPE and labor compensation. The United Nations reports US aircraft exports and US total exports (by destination), as well as other countries' imports of aircraft and all commodities. 
Dependent Variable: US FDI, 1978-1982/US FDI Stock at Yearend 1977

$\begin{array}{lcccc}\text { Constant } & 0.3359 & 0.3210 & 0.4143 & 0.3895 \\ & (0.1552) & (0.2037) & (0.1622) & (0.1463) \\ \begin{array}{l}\text { GDP, } 1977 \\ (\$ 100 \text { b) }\end{array} & & & -0.0359 & -0.0275 \\ & & (0.0291) & (0.0262) \\ \text { \% } \Delta \text { GDP } & 2.9395 & & & \\ & (0.7090) & (1.0950) & 2.9958 & 2.9214 \\ & & & (0.6894) & (0.7178) \\ \text { \% } \Delta \text { FDI, } & -0.0184 & 0.0079 & -0.0234 & 0.0233 \\ \text { all countries } & (0.0497) & (0.0680) & (0.0486) & (0.0437) \\ & & & & \\ \text { Corruption Level } & -0.1070 & & -0.1167 & \\ & (0.0460) & & (0.0458) & \\ \text { Corruption Dummy } & & & & -0.6734 \\ & & -0.4804 & & (0.2607)\end{array}$

No. obs.

Note: The dependent variable is the ratio of US FDI, 1978-1982, to the US FDI stock at yearend 1977. The variable "\% $\Delta$ FDI, all countries" is the ratio of total foreign direct investment, 19781982, to the "stock" of FDI from all countries at the end of 1977. The variable "Corruption Level" is (10-the BI corruption index); larger numbers correspond to greater degrees to which business transactions involve corruption or questionable payments in 1980. The Corruption Dummy variable equals 1 if the BI corruption index is 0-7 (more corrupt countries), and is zero otherwise. The columns report coefficients that minimize the sum of absolute deviations; standard errors are in parentheses. 
Dependent Variable: \% Change in PPE - \% Change in Labor, 1977-1982

\begin{tabular}{|c|c|c|c|c|}
\hline Constant & $\begin{array}{l}-0.0811 \\
(0.1088)\end{array}$ & $\begin{array}{l}-0.0792 \\
(0.1457)\end{array}$ & $\begin{array}{l}-0.0996 \\
(0.0861)\end{array}$ & $\begin{array}{c}-0.0344 \\
(0.2364)\end{array}$ \\
\hline $\begin{array}{l}\text { GDP, } 1977 \\
(\$ 100 \text { b) }\end{array}$ & & & $\begin{array}{c}0.0119 \\
(0.0186)\end{array}$ & $\begin{array}{l}-0.0057 \\
(0.0611)\end{array}$ \\
\hline$\% \Delta \mathrm{GDP}$ & $\begin{array}{c}2.4117 \\
(0.4341)\end{array}$ & $\begin{array}{c}2.3834 \\
(0.6236)\end{array}$ & $\begin{array}{c}2.4222 \\
(0.2889)\end{array}$ & $\begin{array}{c}2.2863 \\
(0.8417)\end{array}$ \\
\hline Corruption Level & $\begin{array}{l}-0.0731 \\
(0.0275)\end{array}$ & & $\begin{array}{l}-0.0739 \\
(0.0211)\end{array}$ & \\
\hline Corruption Dummy & & $\begin{array}{l}-0.5607 \\
(0.2158)\end{array}$ & & $\begin{array}{l}-0.6085 \\
(0.3106)\end{array}$ \\
\hline No. obs. & 41 & 41 & 41 & 41 \\
\hline
\end{tabular}

Note: The dependent variable is the difference between the growth rate of US affiliates' property, plant, and equipment between 1977 and 1982, and the growth rate of their labor expenditures over the same period. The variable "Corruption Level" is (10-the BI corruption index); larger numbers correspond to greater degrees to which business transactions involve corruption or questionable payments in 1980. The Corruption Dummy variable equals 1 if the BI corruption index is $0-7$ (more corrupt countries), and is zero otherwise. The columns report coefficients that minimize the sum of absolute deviations; standard errors are in parentheses. 


$\begin{array}{lcccc}\text { Constant } & 0.0503 & 0.0387 & 0.0308 & 0.0010 \\ & (0.0906) & (0.0882) & (0.1320) & (0.1166) \\ \begin{array}{l}\text { GDP, } 1977 \\ (\$ 100 \text { b) }\end{array} & & 0.0205 & 0.0106 \\ & & & (0.0327) & (0.0293) \\ \text { \% } \Delta \text { GDP } & 1.2900 & 1.2615 & 1.2861 & \\ & (0.4021) & (0.4088) & (0.4842) & 1.2686 \\ & & & & (0.3892) \\ \text { \% } \Delta \text { PPE, } & 0.6037 & 0.6162 & 0.6125 & 0.6318 \\ \text { majority owned } & (0.0677) & (0.0668) & (0.0842) & (0.0713) \\ \text { Corruption Level } & -0.0447 & & & \\ & (0.0205) & & -0.0462 & \\ \text { Corruption Dummy } & & & (0.0262) & \\ & & -0.2703 & & -0.2645 \\ & & (0.1240) & & (0.1337)\end{array}$

No. obs.

Note: The dependent variable is the rate of growth of US affiliates' property, plant, and equipment (PPE) between 1977-1982. The variable "\% $\triangle$ PPE, majority-owned" is the growth rate of US majority-owned affiliates' PPE over the same period. The variable "Corruption Level" is (10-the BI corruption index); larger numbers correspond to greater degrees to which business transactions involve corruption or questionable payments in 1980. The Corruption Dummy variable equals 1 if the BI corruption index is 0-7 (more corrupt countries), and is zero otherwise. The columns report coefficients that minimize the sum of absolute deviations; standard errors are in parentheses. 
Appendix Table 5

Minimum Absolute Deviation Estimates of US Aircraft Exports after 1977

Dependent Variable: (US share of aircraft imports 1981/82 - US share 1976/77)

Constant

$-0.0301$

$(0.1175)$

$-0.0279$

(0.0981)

0.0254

(0.1222)

$-0.0305$

$(0.0317)$

2.1467

(2.0164)

(2.1245)

(2.2012)

$-0.0465$

(0.0312)
$-0.0592$

(0.0310)
Corruption Level
0.0446

$(0.1300)$

$-0.0562$

(0.0374)

2.6109

(2.3006)

$-0.1973$

$-0.3047$

Corruption Dummy

(0.1581)

(0.1810)

No. obs.

42

42

42

42

Note: The dependent variable is the difference between the US share of aircraft imports in 1981/82 and the same share in 1976/77. The variable " $\Delta$ US Share Total Imports" is the difference between the US share of a country's imports of all goods in 1981/82 and the same share in 1976/77. The variable "Corruption Level" is (10-the BI corruption index); larger numbers correspond to greater degrees to which business transactions involve corruption or questionable payments in 1980 . The Corruption Dummy variable equals 1 if the BI corruption index is 0-7 (more corrupt countries), and is zero otherwise. The columns report coefficients that minimize the sum of absolute deviations; standard errors are in parentheses. 
Dependent Variable: Total FDI, 1978-1982/FDI Synthetic Stock at Yearend 1977

\begin{tabular}{lcccc} 
Constant & 1.0955 & 1.1982 & 1.1262 & 1.2023 \\
& $(0.4973)$ & $(0.4900)$ & $(0.5666)$ & $(0.5515)$ \\
$\begin{array}{l}\text { GDP, } 1977 \\
(\$ 100 \text { b) }\end{array}$ & & & -0.0119 & -0.0018 \\
\% $\Delta$ GDP & -0.7011 & -1.0847 & $(0.0994)$ & $(0.1033)$ \\
& $(2.5561)$ & $(2.9664)$ & -0.6921 & -1.0754 \\
Corruption Level & 0.1081 & & $(2.5975)$ & $(3.0598)$ \\
& $(0.1556)$ & & 0.1057 & \\
Corruption Dummy & & 0.6409 & $(0.1594)$ & \\
& & $(0.9836)$ & & 0.6355 \\
& & & & $(1.0464)$ \\
& & & & \\
& & & & -0.082 \\
Adj. $R^{2}$ & -0.046 & -0.048 & -0.079 & 35 \\
No. obs. & 35 & 35 & 35 & \\
\hline
\end{tabular}

Note: The dependent variable is the ratio of total foreign direct investment, 1978-1982, to the "stock" of FDI from all countries at the end of 1977. The variable "Corruption Level" is (10-the BI corruption index); larger numbers correspond to greater degrees to which business transactions involve corruption or questionable payments in 1980. The Corruption Dummy variable equals 1 if the BI corruption index is 0-7 (more corrupt countries), and is zero otherwise. The columns report estimated OLS coefficients; standard errors are in parentheses. 
Dependent Variable: (aircraft share of total imports 1981/82 - aircraft share 1976/77)

\begin{tabular}{lcccc} 
Constant & 0.0067 & 0.0065 & 0.0051 & 0.0048 \\
& $(0.0021)$ & $(0.0019)$ & $(0.0026)$ & $(0.0024)$ \\
GDP, 1977 & & & 0.0008 & 0.0008 \\
$(\$ 100$ b) & & & $(0.0007)$ & $(0.0007)$ \\
Corruption Level & -0.0005 & & -0.0003 & \\
& $(0.0006)$ & & $(0.0006)$ & \\
Corruption Dummy & & -0.0025 & & -0.0012 \\
& & $(0.0032)$ & & $(0.0033)$ \\
& & & & \\
& & & -0.002 & -0.004 \\
Adj. $\mathbf{R}^{2}$ & -0.009 & -0.010 & 42 & 42 \\
No. obs. & 42 & 42 & & \\
\hline
\end{tabular}

Note: The dependent variable is the difference between the share of total imports represented by aircraft (CTC 734) in 1981/82 and the same share in 1976/77. The variable "Corruption Level" is (10-the BI corruption index); larger numbers correspond to greater degrees to which business transactions involve corruption or questionable payments in 1980. The Corruption Dummy variable equals 1 if the BI corruption index is 0-7 (more corrupt countries), and is zero otherwise. The columns report estimated OLS coefficients; standard errors are in parentheses. 